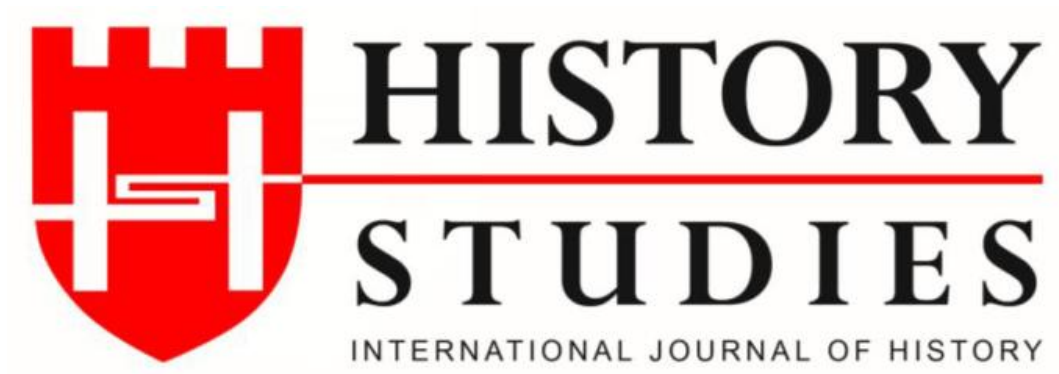

ISSN: 13094173 (Online) 1309 - 4688 (Print)

Volume 11 Issue 1, p. 91-106, February 2019

DOI: $10.9737 /$ hist.2019.709

Makalenin Geliş Tarihi: 02.01.2019 - Kabul Tarihi: 29.01.2019

\title{
Macarların Avrupa'daki İlk Büyük Muharebesi: Pozsony Muharebesi (4-5 Temmuz 907)
}

The First Big Battle of the Hungarians in Europe: The Pozsony Battle (4-5 July 907)

\author{
Dr. Gökhan DİLBAŞ
}

ORCID No: 0000-0003-4337-8700

\begin{abstract}
Öz: 895-896 yıllarında Karpatlar Havzası'na gelen Macarlar, topraklarını batıya doğru genişletirken bu coğrafyada hâkimiyet kurmak isteyen Doğu Frank Krallı̆̆ ile karşı karşıya gelirler ve onunla mücadeleye başlarlar. Bu mücadele sürecinde 4-5 Temmuz 907 tarihinde Macarlar ve Doğu Frank Krallı̆̆ arasında yaşanan Pozsony Muharebesi'nin ayrl bir yeri ve önemi bulunmaktadır. Muharebenin sonunda sadece Karpatlar Havzası'ndaki yerlerini değil, aynı zamanda Avrupa'daki varlıklarını da sağlamlaştıran Macarlar, bu tarihten sonra topraklarını daha rahat şekilde genişletme imkânına da sahip olurlar. Macar tarihinin önemli gelişmelerinden birisi olan Pozsony Muharebesi'nin incelenmesi ve değerlendirilmesi Macarların nihai yurtlarını ne şekilde elde ettiğini anlatırken, aynı zamanda X. yüzyıl Orta Avrupa tarihine de bir ışık tutacaktır.
\end{abstract}

Anahtar Kelimeler: Pozsony Muharebesi, Macarlar, Doğu Frank Krallığı, Yurt Tutuş, Karpatlar Havzasl.

\begin{abstract}
The Hungarians coming down to the Carpathian Basin in 895-896 with a drive to expand their territory out towards the West have experienced a challenge from the Kingdom of the East Franks also having an urge to enjoy a sovereignty over this geography, and thus started up a struggle with them. The Pozsony Battle which broke out between the Hungarians and the Kingdom of the East Franks on 4 and 5 July 907 has a distinct place and significance in the process of this struggle. At the end of this battle, the Hungarians have not only strengthened their place in the Carpathian Basin but also reinforced their existence in Europe and, thereafter, have had an opportunity to further expand their territory more easily. A study and evaluation of the Pozsony Battle, being one of the crucial developments in the Hungarian history, unveil how did the Hungarians embrace their final homeland, while, also, shedding some light on the Xth century Central Europe history.
\end{abstract}

Key words: The Pozsony Battle, The Hungarians, Kingdom of the East Franks, Conquest, Carpathian Basin.

\section{Giriş}

Macarların ataları M.Ö. 4000 yıllarında Ural Dağları civarında yaşayan Fin-UgorSamoyed toplulukları içerisinde yer alır. Fin-Ugor dil birliği yaklaşık olarak M.Ö. 2000 yıllarına doğru dağılır ve Fin-Ugor ana kavmi batı ve doğu olmak üzere ikiye ayrılır. Fin-Perm şeklinde adlandırılan batı kolu Züryen, Votyak, Çeremiş, Mordvin, Fin ve Est kavimlerinden meydana gelirken Ugor diye adlandırılan doğu kolu ise Ostyaklar, Vogullar ve Macarların atalarından oluşur. ${ }^{1}$

\footnotetext{
${ }^{1}$ Naciye Güngörmüş, Macaristan'da Değişim ve Demokrasiye Geçiş (1989-2009), Siyasal Kitabevi, Ankara 2010, s. 19; F. Eckhart, Macaristan Tarihi, Çev: İbrahim Kafesoğlu, 2. Baskı (Tıpkı basım), Türk Tarih Kurumu
} 
Zaman içinde Manysi adını almış olma ihtimali de bulunan Ugor kolu, Ural Dağları'nın Avrupa'ya bakan batı yamaçlarına çekilerek burada yaşamaya başlar. Bununla birlikte Ugor kolunun bir bölümünün Ural Dağları'nın doğu kısmına, yani Asya'ya bakan yamaçlara çekildiği de bilinmektedir. Macarların ataları Türk kavimlerinin en batısında yer alan Onogurlar ile temas eder ve bu temasın sonucunda eski yaşam tarzlarını bırakarak step kuşağının atlı-göçebe hayat tarzına adapte olur. Manysilerin ve Onogurların zaman içinde karışması Macar kavminin temelini oluşturur. ${ }^{2}$

Macarlar, M.S. III veya IV. yüzyılda göç ederek bugünkü Başkurdistan sahasına gelirler ve Magna Hungaria diye adlandırılan bölgede yaşarlar. Macarlar Hungarian, Hongeais, Ungarn, Ugri, Ungar, Hongrois, Venger vb. isimleri de Onogurlar sayesinde kazanırlar. ${ }^{3}$

M.S. 460 civarında Avar-Sabir dalgası Macarları önce kısa bir süre ikamet ettikleri Kuban çevresine, oradan da 830 civarında Levédia diye adlandırdıkları Don ve Dinyeper nehirleri arasına sürükler. Macarlar, bu sahada "Yedi Macar" diye bilinen kavim birliğini tesis ederler. Bu coğrafyada Hazar İmparatorluğu'nun yönetimi altında yaşayan Macarların başında kündü (kende) ve gyula unvanlarını taşıyan iki yönetici bulunmaktadır. ${ }^{4}$

889 yılında Peçeneklerin baskısıyla göç etmek zorunda kalan Macarlar, Etelköz diye adlandırdıkları Prut, Dinyester ve Dinyeper nehirleri arasına gelirler. Bu sahada yedi Macar kavminin (Megyer/Magyar, Nyék, Kürt-Gyarmat, Tarjan, Jenő, Kér. Bundan başka Macarlara Hazarlardan ayrılarak katılan Kabarlar da vardır) en güçlüsünün başında bulunan Álmos'u (?895 civar1) kendilerine reis seçerler. ${ }^{5}$

Macarlar, Bulgar-Peçenek saldırısı sonucunda 895-896 yıllarında Karpat Dağları'ndaki Verecke Geçidi'ni aşarak Karpatlar Havzası'na gelirler. Honfoglalás (Yurt Tutuş) olarak anılan bu olay Macar tarihinin dönüm noktalarından birisi olduğu gibi, Avrupa tarihinde de bir dizi olayın başlangıcıdır. Macarlar, Etelköz'deki yurtlarında Doğu Frank Kralı Arnulf'un (887899) Moravya Prensliği’ne karşı yaptığı akınlarda müttefiki olarak nihai yurtları olacak olan Karpatlar Havzası'nı tanıma firsat da bulurlar. ${ }^{6}$ Zira Arnulf daha 892 yılında Moravya Prensi Svatopluk'a (870-894) karşı Macarlardan yardım ister ve Macarların desteği ile Moravya Prensliği’nin gücünü kırar. ${ }^{7}$ Dolayısıyla bu coğrafya Macarlara yabancı değildir.

Macar kavimleri geldikleri bu yeni coğrafyada iskân hareketlerine başlarlar. Göçebe yaşam şekillerini devam ettirebilmek için 896-898 yıllarında batıya doğru yayılarak TunaGaram hattında ilerlerler ve Tuna ötesi arazilerinde hâkimiyet kurarlar. Bu şekilde Doğu Frank Krallığ topraklarına yaklaşmış olurlar. ${ }^{8}$

\section{Pozsony Muharebesi Öncesi Yaşanan Gelişmeler}

Doğu Frank Kralı Arnulf’un 899 yılındaki ölümünden sonra 899 yılında Macarlar ve Arnulf arasında yapılmış olan Macarların sadece Karpatlar Havzası'nın doğu kısmına hâkim olacakları şeklindeki antlaşmanın da bir hükmü kalmaz. Macarlar, 900 yılından itibaren Garam ırmağından batıya doğru akınlara başlarlar. Macarların yaptığı bu akınlar başta Doğu Frank

Basımevi, Ankara 2010, s. 3; László Rásonyi, Tarihte Türklük, Üçüncü Bask1, Türk Kültürünü Araştırma Enstitüsü Yayınları: 126, Seri: III - Sayı: A.34, Ankara Üniversitesi Basımevi, Ankara 1993, s. 118.

${ }^{2}$ Rásonyi, age, s. 118-119.

${ }^{3}$ Güngörmüş, age, s. 19; Eckhart, age, s. 5; Rásonyi, age, s. 119; Gyula Kristó-János Barta-Jenő Gergely, Magyarország Története Elöidőktől 2000-ig, Pannonica Kiadó, (basım yeri belirtilmemiş) 2002, s. 14.

${ }^{4}$ Eckhart, age, s. 5, 8; Rásonyi, age, s. 119-120; Kristó vd., age, s.15.

${ }^{5}$ Eckhart, age, s. 6; Rásonyi, age, s. 121; Kristó vd., age, s. 16.

${ }^{6}$ Güngörmüş, age, s. 22; Eckhart, age, s. 9.

${ }^{7}$ Lajos Négyesi, “A pozsonyi csata”, Rubicon, (27. évf.), 7. sz., 2016, s. 36; Eckhart, age, s. 11.

${ }^{8}$ Güngörmüş, age, s. 22; Kristó vd., age, s. 21. 
Krallığ sınırları içinde yer alan Bavyera bölgesi olmak üzere tüm Doğu Frank Krallığı'nı (840-962) kaygilandırır. Pozsony Muharebesi'nin en önemli sebebi, Macarların Fischa/Lajta 1rmağ1 çizgisinden ve Moravya 1rmağından doğuya doğru bütün Kisalföld'ü (Macaristan'ın kuzeybatı bölümünü kaplayan bölge) ele geçirip hâkim olmaları ve Doğu Frank Krallığı'nı tehdit ve tedirgin etmeleridir. Zaten daha 900 yilında Macar reislerinden Kurszán (?-904), Pannonia'nın (günümüzde Macaristan'ın batı, Avusturya'nın doğu bölgelerini, Slovenya, Hırvatistan ve Sırbistan'ın bir kısmını da içine alan tarihi bölge) neredeyse tamamını ele geçirir ve Macar sınır hattının batısında yer alan savunma kuşağını Ostmark (günümüzde Aşağı Avusturya) arazilerinin sınır çizgisine kadar genişletir. Macarlar, 900 yılına kadar Alföld'ün (Macaristan'ın güneydoğu kısmını kaplayan, Hırvatistan, Sırbistan ve Romanya'ya da yayılan büyük ova) güney bölgelerinde - Bánság, Temesköz ve Bácska - durumlarını güçlendirirler ve Szerémség'i de elde ederler. Böylece topraklarını Doğu Frank Krallığı aleyhine genişletmiş olurlar. Macarların topraklarını genişletmesinden ve güçlenmesinden rahatsızlık duyan Bulgar Çarı Simeon (893-927) Macar ilerleyişini önlemek istese de başarılı olamaz. $^{9}$

899-900 yıllarından sonra Macarlar seferlerini İtalya’ya doğru yayarlar. Öncelikle Kuzey İtalya'da başarılar elde ederler, hatta 24 Eylül 899 tarihinde İtalya Kralı I. Berengár'ın (İtalya Kralı: 887-924, Frank İmparatoru: 915-924) birliklerini Brenta ırmağı yanında bozguna uğratırlar. Bu muharebe Macarların Karpatlar Havzası'na girişinden sonra yapılan ilk ciddi muharebedir. ${ }^{10}$ Sváb (Suabiya) Yıllığı'na göre Macarlar 901 yılında İtalya'ya girer. Aynı yıl Fulda Yıllıkları'na (864-901 yılları arasındaki olayları anlatan Alman yıllıkları) göre Macarlar, Mura vadisi boyunca Karinthia'ya da (Avusturya'nın güney bölümü) akınlar yapar. 906'da Drava ve Sava arası Macarlar tarafından ele geçirilir ve Macarlar, Po Ovası'na da erişirler. ${ }^{11}$

902-906 yılları arasında Macarların Karpatlar Havzası'ndaki konumlarını güçlendirmeleri ve elde ettikleri sahaları berkitmeleri Pozsony Muharebesi'nin ikinci önemli sebebidir. Macarlar, 906 yılında Moravya Prensliği'nin ordusunu mağlup ederler ve Moravya Prensliği tarihe karışır. $^{12}$ Macarlar ve Doğu Frank Krallığı arasındaki tampon bölgenin kaybı Doğu Frank Krallığı'nı iyice endişelendirir, bölgede gerilim ve gerginlik eksik olmaz. Bu gelişme Macarların elde ettiği toprakları muhafaza etmek için sürekli olarak büyük miktarda kuvvet bulundurmasını gerektirir. ${ }^{13}$ Bundan başka Bavyeralıların, Karpatlar Havzası'nın elde edilmesinde büyük rolü bulunan Reis Kurszán'1 (Kursál, Kusán) 904 - bazı kaynaklar 902 demektedir $^{14}$ - yılında bir ziyafete davet ederek onu ve maiyetini tuzağa düşürüp öldürmesi zaten gergin olan ortamı daha da gerginleştirir. ${ }^{15}$ Macarların Tuna çizgisinde yapmakta oldukları akınlar, Enns'e kadar ilerlemeleri ve durmak bilmeyen saldırılarını önlemek için Doğu Frank Krallığı, Ennsburg Kalesi’ni inşa etmek zorunda kalır. Bu kale, Macarların 900

\footnotetext{
${ }^{9}$ Lajos Gubcsi, 1111 évvel ezelöt A 907-es pozsonyi csata, 2018, s. 4; Négyesi, agm., s. 36; Béla Gyula Torma, "A 907. Évi Pozsonyi Csata Katonapolitikai Háttere És Hadművészeti Modellezése”, Egy Elfeledett Diadal. A 907. Évi Pozsonyi Csata, Sz. Torma Béla Gyula és Veszprémy László, Budapest 2008, s. 13.

${ }^{10}$ László Sipka, “A győztes pozsonyi csata 1100. évfordulójára”, Honismeret, 35. évfolyam, 6. sz., 2007, s. 4.

${ }^{11}$ Gubcsi, age, s. 4-5; Négyesi, agm, s. 36; György Szabados, "907 emlékezete”, Tiszataj, 61. évf., 12. sz., 2007, s. 68; Bálint Hóman-Gyula Szekfü, Magyar Történet, Királyi Magyar Egyetemi Nyomda, Budapest, 1928; Kálmán Nagy, “A 895. Évi Honfoglalás”, Magyar Történelem Tízezer év-ezer oldalról, Szerkesztő: Csihák György, Acta Historica Hungarica Turiciensia, XVIII. évfolyam, 1. szám, ZMTE (Zürichi Magyar Történelmi Egyesület), 37. sz. kiádvanya, Zürich-Budapest, 2002, s. 370; Torma, age, 2008, s. 12.

${ }^{12}$ Gubcsi, age, s. 4; Hóman-Szekfü, age; Nagy, age, s. 370.

${ }^{13}$ Gubcsi, age, s. 4.

${ }^{14}$ Szabados, agm, 2007, s. 68; Kristó vd, age, s. 22.

${ }^{15}$ Gubcsi, age, s. 4; Hóman-Szekfü, age; Torma, age, 2008, s. 23.
} 
yılındaki akınından sonra hızlı bir şekilde inşa edilir. ${ }^{16} 906$ yılında Macarlar artık Enns'den doğuya doğru olan sahaları kontrol etmekte ve Saksonya'ya da akınlar yapmaktadır. ${ }^{17}$

900 yılından 906 yılına kadar yaşanan gelişmeler Macarların Karpatlar Havzası'nda esaslı bir şekilde yerleşmekte ve hâkimiyetlerini genişletmekte olduklarını gösterirken, Doğu Frank Krallığı'nın Karpatlar Havzası'nda yeni, sağlam ve güçlü bir oluşum istemediğini, mülkü olarak gördüğü Pannonia'yı korumayı amaçladığını ve Frankların bir kısmını Moravya'da ve Pannonia'da ikamet ettirmeye kararlı olduğunu ortaya koymaktadır. ${ }^{18}$

Karpat Dağları'nın doğusunda yüzyıl dönümü civarında Peçenekler, Macarların terk ettiği Etelköz'deki (Dinyester, Dinyeper ve Prut ırmakları arasında olan bölge) sahalara yerleşirler ve Macarların Karpatlar Havzası'ndan çıkış yollarını kapatırlar. Öte yandan güney ve güneybatı yönünde ise bir Bulgar-Peçenek ittifakı ve saldırısı ihtimali de Macarları tedirgin etmektedir. ${ }^{19}$ Batı yönünde ise Doğu Frank Krallığı bulunmaktadır. Macarların Karpatlar Havzası'ndan çıkış yollarının kapanmış olması Macar kavim birliğinin bu coğrafyada varlığını devam ettirmek istiyorsa olası tüm saldırılara güçlü şekilde karşı koyabilecek askeri bir kuvvete sahip olmasını ve hasımlarını bir an önce alt ederek Karpatlar Havzası'ndaki varlığını güçlendirmesine bağlıdır. ${ }^{20}$ Zaten Macarlar da bunun farkındadır. Zira geçmiş tecrübelerine dayanarak (Bulgar saldırıları, Bulgar-Peçenek saldırısı ve Reis Kurszán'ın ölümü) Macarları çok sayıda kuvvet bulundurmaya ve sürekli şekilde bir saldırıya hazır halde beklemeye yöneltir.

Karpatlar Havzası'ndaki gelişmeleri takip eden ve Macarların gücünün daha 900'lü yılların başında farkına varan Doğu Frank Krallığı ise ilerleyen yıllarda yaşanan gelişmelerin de etkisiyle dış politikasını buna göre şekillendirir ve Macarlarla yapılan mücadeleyi ilk sıraya koyar. Durumun gitgide ciddileşmesi üzerine de 907 yılının Mayıs-Haziran aylarında Macarlara karşı bir sefer yapmaya karar verir. ${ }^{21}$

\section{Pozsony Muharebesi (4-5 Temmuz 907)}

Gelişmeler karşısında Doğu Frank Krallığı, Macarları artık Karpatlar Havzası'nda barındırmak istemez ve onların gücünü kırmayı, hatta bir adım öteye geçerek onları Karpatlar Havzası'ndan çıkarmaya karar verir. Bu sırada Doğu Frank Krallığı'nın başında Arnulf'un oğlu, on dört yaşında olan IV. (Çocuk) Lajos (900-911) bulunuyordu. Macarları, Karpatlar Havzası'ndan çıkarmak amacıyla yapılan seferin hazırlıkları "decretum... Ugros eliminandos esse / Macarları imha etmek için hazırlanın" şeklinde verdiği emirle başlar. ${ }^{22}$ Bavyeralı kronik yazarı Johannes Aventinus (1477-1534, orijinal ismi Johann Georg Turmair) başlangıçtan 1460'lı yıllara kadar Bavyera'nın tarihini anlatan Bajor évkönyv (Bayrischer Chronicon, Bavyera Yıllığı) adlı eserinde seferin başlama kararı ile ilgili şunları yazar: “... ibi decretum omnium sententia Ugros Boiariae regno eliminandos esse / Orada hep birlikte Macarlartn Bavyera toprağından çıkarılması gerektiğine karar verdiler". ${ }^{23} \mathrm{Kral}$, ordunun yönetimi için Kont - bazı kaynaklara göre Bavyera Prensi ${ }^{24}$ - Luitpold'a (Liutpold, Luitbald, ?-907) ve Salzburg Başpiskoposu Theotmár’a (Dietmar, 874-907) güvenirken Tuna ırmağındaki filonun

${ }^{16}$ Torma, age, 2008, s. 18.

${ }^{17}$ Négyesi, agm, s. 36.

${ }^{18}$ Gubcsi, age, s. 4.

${ }^{19}$ Gubcsi, age, s. 5; Torma, age, 2008, s. 13.

${ }^{20}$ Gubcsi, age, s. 7.

${ }^{21}$ Gubcsi, age, s. 7.

22 Árpád Péter Harmat, “A pozsonyi csata (907 július 4-5)”, 2012.

${ }^{23}$ András Pöstényi, Már Kiirtani Sem Akarták A Magyarokat?, 2015.

${ }^{24}$ József Bánlaky, "A magyar nemzet hadtörténelme”, (Digitális kiadás: Arcanum Adatbázis Kft.), 2001. 
idaresini Prens Siegrad'a (Sigrad, Sighrad) emanet eder. ${ }^{25}$ Bavyera birlikleri Kral IV. Lajos'un emriyle Enns 1rmağının gerisinde bulunan Markt St. Florian-Raffelstetten sahasında 907 yılının Mayıs-Haziran aylarında toplanmaya başlar. ${ }^{26}$ Kaynakların bir kısmı ordunun Ennsburg'taki (Anesapurc) kale civarında toplandığını ve genel itibariyle Nariscus, Boethus, Chambus, Vindelicus, Noricum, Vennoni, Athenis, Stájer, Vend, Karinthia, Karajna bölgelerinin askerlerinden oluştuğunu yazmaktadır. Bu durum itibariyle ordu ağırlıklı olarak bugünkü Avusturya'nın doğu kısmında oturan halklardan meydana gelmektedir. ${ }^{27}$

St. Florian Manastırı'nda yer alan bir kayda göre ordu, 17 Haziran 907 tarihinde Tuna ırmağını ortasına alarak ırmağın kuzey ve güney kıyısında iki kol halinde ilerlemeye başlar. Kuzey kolunu sinır bölgelerinin yöneticisi Kont Luitpold, güney kolunu ise Salzburg Başpiskoposu Theotmár yönetmektedir. Bundan başka ordunun güney kolunda Säben Piskoposu Zakariás, Freising Piskoposu Udo ve keşişler Gumpold, Hartwich (Hartvik) ve Helmbert de bulunmaktadır. Ordunun ilerleyişine piyade birliklerinin bir kısmını taşıyan ve ilerlemekte olan birliklere iaşe malzemesi sağlayan Tuna filosu da destek vermektedir. Filoyu Kralın akrabası Prens Siegrad idare ediyor, filoda ayrıca Rathold, Hattó, Meginward ve Isangram (Eisengrin) gibi Bavyera asilzadeleri de bulunuyordu. Kral IV. Lajos ise Passau Başpiskoposu Burghard ve Kont Aribó ile birlikte yedek kuvvetlerle Ennsburg'da kalır. ${ }^{28}$ Aventinus geliş̧meleri şöyle anlatır:

“Germania'nın ve Bavyeralıların kralı Lajos bütün Bavyera geneline yayılan askere alma işleminden sonra Bavyeralıların yeni şehrine, Ennsvár'a gelir... Macarlara karşı savaş ilan edilir, Tuna'nın her iki kıyısında Bavyera ileri gelenleri ve taarruz birlikleri savaşa hazırlanmaya başlar. Lajos, Passau Piskoposu Buchard ve vali Aribó ile birlikte Ennsburg'da kalır. Komutanlar birlikleri üç kısma ayırır. Avusturya sinır komutanı olan Luitpold kuzey klyısında, Salzburg Başpiskoposu Theotmár güney klylsında ilerler... Tuna üzerindeki gemilerde birlikleri Kralın akrabası, Semnonların [bir Alman kavmi] yöneticisi Sighard ve Bavyeralı beyler Rathold, Hattó, Meginward ve Isangrim yönetirler" 29

Ordunun yürüyüşü esnasında ortaya çıkan ihtiyaçlar ve askerlerin iaşesi Tuna 1rmağının her iki kıyısında aşağı yukarı her otuz kilometrede bir yer alan Roma İmparatorluğu döneminde tesis edilmiş liman yerlerinde karşılanmaktadır. Bavyera filosu sefer boyunca hem güney, hem de kuzey koluna lojistik ve iaşe konularında destek verir. Bundan başka filo yoluyla nakledilen piyade birlikleri de daha ziyade kuzey koluna takviye yapar ve filo, her iki kol arasında iletişim de sağlar. Güney kolu daha elverişli arazi şartlarından ve limes (Antik Roma döneminde sinırları koruyan sistem) yolunu takip etmesinden dolayı kuzey kolundan önde gider ve 24 Haziran 907 tarihinde Wienerwald civarında Tuna ırmağını karşıya geçer, ırmağı takip ederek hızlı bir yürüyüşle Viyana Havzası'nın doğu bölümüne ilerler. ${ }^{30}$

Bu sırada sınır boylarını kontrol eden Macar birlikleri, Greifenstein arazisinde Bavyera ileri kuvvetlerini fark eder ve derhal sınır birliklerini ve yerleşim bölgelerinde bulunan birlikleri uyarır. Anonymus'a (Kral III. Béla'nın [1172-1196] kâtibi olduğu tahmin edilen kronik yazarı. Yapılan araştırmalara rağmen adı tam olarak ortaya çıkarılmadığından

\footnotetext{
${ }^{25}$ Harmat, agm, 2012.

${ }^{26}$ Gubcsi, age, s. 8.

${ }^{27}$ Négyesi, agm, s. 36.

${ }^{28}$ Gubcsi, age, s. 8; Négyesi, agm, s. 36; Bánlaky, age; Crescens Lajos Dedek, "Pozsony Vármegye Története", Magyarország Vármegyéi és Városai, Szerkesztő: dr. Borovszky Samu (Digitális kiadás: Arcanum Adatbázis Kft.), 2004; Torma, age, 2008, s. 14.

${ }^{29}$ Szabados, age , 2015, s. 90.

${ }^{30}$ Gubcsi, age, s. 8, 10-11; Négyesi, agm, s. 37; Torma, age, 2008, s. 45, 50.
} 
Anonymus [İsimsiz] olarak bilinir) göre bu zamanda yapılan seferler ve sınır güvenliği gibi meselelerle Macar reisleri Lél (Lehel, ?-955), Bulcsú (?-955) ve Botond (?-?) meşgul olmaktadır. Bu reislerin çağrısı üzerine 27 Haziran'a kadar Macar birlikleri (sınır savunma birlikleri, Tuna ötesindeki birlikler, kavimlerin ve asilzadelerin silahlı maiyetleri) Vág ırmağının gerisinde hızlı bir şekilde toplanır ve ilerlemekte olan Frank ordusunu karşılamak üzere güneybatı yönünde harekete geçer. ${ }^{31}$ Macarlar, Frank kuvvetlerini mümkün olduğu kadar sınır boylarından içeride karşılamak için Pozsony'a kadar gelmelerine izin verir. Böylece Bavyera ordusunu ikmal merkezinden uzaklaştırırlar ve gücünü azaltıp fiziki olarak da yorarlar. ${ }^{32}$ Ayrıca yeteri kadar kuvvet toplamak için de zamanları olur. Nitekim Macarlar bu zamanda saldırılara sürekli hazır halde olduklarından ve macera seferleri gerçekleştirdiklerinden dolayı askeri birliklerini hılı bir şekilde bir araya getirebilecek tecrübeye sahiptir. ${ }^{33}$

Bu arada X. yüzyılın ilk yarısında Macar yönetim merkezinin (Macar reislerinin ve askeri maiyetin ikametgâh yeri) Yukarı Tisa bölgesinde olması kuvvetli bir olasılıktır. Macar ana kuvvetlerinin 907 yılında diğer kuvvetlerle bu sahada bir araya gelerek batıya, sınır boylarına buradan ilerlemiş olması olasılığ 1 da gözden kaçırılmamalıdır. ${ }^{34}$ Macar ordusunun toplanma yerinin Rákos ovası olması da düşünülmesi gereken bir başka olasılıktır. Zira Macar birliklerinin buradan hareket etmesi ve muharebede izlenecek taktiğin burada kararlaştırılmış olması da güçlü bir ihtimaldir. Bu ihtimali değerlendirecek olursak Macar ordusunun bir kısmının Tuna ırmağının sağ kıyısında ilerlemekte olan Bavyera birliklerini karşılamak için 1rmaktan karşıya geçtiği ve Vértes Dağları boyunca ilerlediğini düşünmemiz gerekir. Macar ordusunun diğer kolu ise Tuna ırmağının sol kıyısında Felsővidék’teki kaleler boyunca ileri hareketine devam etmiş olmalıdır. ${ }^{35}$

Tuna ırmağı üzerinde hareket eden filo, Pozsony önüne geldiği zaman ırmakta ilerlemenin güçleştiğini görür. $\mathrm{Bu}$ yüzden hem Tuna ırmağının ikmal malzemelerini taşıyan gemilerin görevini zorlaştırması, hem de ilerlemekte olan birlikleri tehdit edebilecek oluşumların gerçekleşme ihtimalinin artması yüzünden ordu yavaş ilerlemek zorunda kalır. Frank ordusunun kuzey kanadının işi daha zordur. Yol üzerinde bulunan Bana, Sempte, Galgóc ve hatta Nyitra, Macarlar tarafından kontrol edilmektedir. Bu istihkâmlardan başka Macar ileri kuvvetleri sürekli olarak bu kanadı gözetim altında tutmaktadır. Bu durum Macarlar ve Bavyera ordusunun kuzey kolu arasında olası bir çatışma riskini de arttırmaktadır. ${ }^{36}$

$\mathrm{Bu}$ gelişmeler yaşanırken Başpiskopos Theotmár'ın yönetiminde bulunan birlikler 26 Haziran 907 tarihinde Ficsha ırmağına ulaşır ve seferin başından beri ilk defa Macar kuvvetleri ile karşı karşıya gelinir. Macarların ilk karşı koyması da bu sahada yaşanır. Ancak Bavyera ordusu esas mücadeleye başlamak için ikinci kolun, yani Kont Luitpold'un komutasında olan birliklerin de gelmesini beklemek zorundadır. Bunu gören Macarlar, Bavyera baskısını ve ileri hareketini zayıflatmak için küçük birliklerle devamlı surette saldırılar düzenler ve bu saldırıların ardından geri çekilme taktiğini kullanarak Bavyera birliklerini yıpratır ve düzensizliğe sebep olarak asıl kuvvetlerin savaş pozisyonu almasını da engeller. 28 Haziran

\footnotetext{
${ }^{31}$ Gubcsi, age, s. 8; Bánlaky, age.

${ }^{32}$ Dedek, age.

${ }^{33}$ Péter Farkas, “A pogányokkal vívott nagyon szerencsétlen harc”, Aetas, 25. évf., 2. szám, 2010, s. 204.

${ }^{34}$ László Révész, "A 907. Évi Pozsonyi Csata Katonapolitikai Háttere És Hadmủvészeti Modellezése”, Egy Elfeledett Diadal. A 907. Évi Pozsonyi Csata, sz. Torma Béla Gyula és Veszprémy László, 2008 Budapest, s. 194.

${ }^{35}$ Dedek, age.

${ }^{36}$ Dedek, age.
} 
907 tarihinde yaşanan çarpışmada Macar sınır birlikleri saldırılarda bulunarak ilerlemekte olan Bavyera birliklerini yavaşlatmaya ve saflarını bozmaya çalışır. ${ }^{37}$

Macarların Başpiskopos Theotmár'ın birliklerini gözetim altında tutmaları ve devamlı surette tedirgin etmeleri devam ederken 28 Haziran 907'deki çarpışmadan bir gün önce, 27 Haziran 907 tarihinde Kont Luitpold'un komutasındaki Bavyera ordusunun kuzey kolu Stockerau bölgesine, yani Macar sınır savunma kuşağının batı girişine gelir ve Moravya 1rmağından karşıya geçmek için hızlı bir yürüyüşle Moravya ovasında ilerler. ${ }^{38}$

29 Haziran 907 tarihinde ırmağın güney kısmında bulunan Başpiskopos Theotmár'ın yönetimindeki birlikler, Macarların saldırılarına rağmen Hainburg civarına kadar olan sahayı elde ederler ve Tuna ırmağını karşıya geçmek için bir köprübaşı oluştururlar. $\mathrm{Bu}$ arada Macarlar ve Bavyeralılar arasında yaşanan çarpışmaların şiddeti de artmakta, Theotmár, karşı saldırıya geçmek için Kont Luitpold'un kuvvetlerini beklemektedir. ${ }^{39} \mathrm{Bu}$ süre zarfında Tuna ırmağının kuzeyinde henüz yeteri kadar Macar birliğinin toplanamamış olması Macarların durumunu zorlaştırmaktadır. Birliklerin büyük kısmı ya Tuna ırmağının güney kısmındadır, ya da muharebe alanına doğru ilerlemektedir. Durum bu haldeyken 1 Temmuz 907 tarihinde Macar sinır savunma birliklerinin ve ana kuvvetlerin bir kısmı Bavyera ana kuvvetleriyle mücadele etmeye başlar. Kont Luitpold ise Tuna filosunun desteğiyle Moravya 1rmağını karşıya geçer ve Pozsony'a on beş kilometre kadar yaklaşarak Dévényi-kapu civarına varır. ${ }^{40}$ Zira Kont Luitpold, Pozsony’a varmak için Doğu Frank Krallığı ve Macarlar arasında doğal bir sınır oluşturan Moravya ırmağını karşıya geçmesi gerektiğini bilmekte ve Macarların da ilk direnişi bu noktada yapabileceklerini tahmin etmektedir. ${ }^{41}$

İlk büyük çarpışma 4 Temmuz 907 tarihinde güney kıyıda, yani Tuna ırmağının sağ tarafında Pozsony'un (o zamanki adı ile Braslauespurch, Brezalauspurc) karşısında Başpiskopos Theotmár'ın birlikleri ile yaşanır. Macarlar önce bir saldırı, ardından sahte bir geri çekiliş taktiği uygular ve birlikleri bu şekilde yorduktan ve şaşırttıktan sonra yapılan muharebede galip gelirler. Başpiskopos Theotmár da bu muharebede hayatını kaybeder. ${ }^{42}$ Arazi şartlarının Macar atlı-okçu birliklerinin lehinde olması Macarların işini kolaylaş̧ırır. Macarlar burada küçük gruplar halinde saldırıp düşman saflarını bozarlar, düşmanı her yandan sardıktan sonra son bir hücumla mağlup ederler. ${ }^{43}$

Bu sırada kuzey kolu arazi şartlarından dolayı ağır hareket etmekte, iaşeleri tam olarak karşılanamamakta, ordunun ihtiyaçları bir ölçüde Tuna nehri üzerinde hareket eden filo tarafından giderilmeye çalışılmaktadır. Gelişmelere bakarak fillonun Viyana'dan sonra yanaşacağ1 en uygun yer Hainburg'un kuzey-kuzeydoğu (Dévény'in bat1-güneybatı) kısmıdır. Tuna filosunun ikmal malzemelerinin ve piyade birliklerinin bir kısmını burada karaya çıkarmış olması kuvvetli bir ihtimaldir. Burası muharebe öncesi Bavyera birliklerinin son toplanma yeri de olmuş olabilir. ${ }^{44}$ Başpiskopos Theotmár'ın birlikleri üzerinde galip gelen Macarlar aynı gece Tuna 1rmağını karşıya geçerler ve Pozsony’un güney-güneydoğu kısmında ordugâh kurmuş olan Kont Luitpold'un birliklerine yaklaşırlar. İkinci muharebe 5 Temmuz 907 tarihinde şafak vakti gerçekleşir. Böyle bir hareket beklemeyen Luitpold'un birlikleri hazırlıksız yakalanır. Macarlar yine Theotmár'ın birlikleri üzerinde uyguladıkları önce bir

${ }^{37}$ Gubcsi, age, s. 8; Harmat, agm, 2012.

${ }^{38}$ Gubcsi, age, s. 9.

${ }^{39}$ Gubcsi, age, s. 9.

${ }^{40}$ Gubcsi, age, s. 9.

${ }^{41}$ Gubcsi, age, s. 11.

${ }^{42}$ Harmat, agm, 2012.

${ }^{43}$ Gubcsi, age, s. 9.

${ }^{44}$ Gubcsi, age, s. 11; Torma, age, 2008, s. 46. 
saldırı, sonra geri çekilme ve ardından son bir hücum taktiğini kullanarak Bavyera birliklerini üzerlerine çekerler, onları her yandan sararlar ve kesin bir galibiyet elde ederler. Macar saldırısı büyük bir ihtimalle Csallóköz ve Sempte yönünden gerçekleşir. Kont Luitpold ile birlikte on dokuz Bavyera asilzadesi de yapılan muharebede hayatını kaybeder. Geriye kalan birlikler güçlükle Ennsburg'a doğru geri çekilir. ${ }^{45}$

Irmağın her iki kıyısında bulunan birliklerin yenilmesinden sonra sıra Tuna irmağ üzerinde bulunan filoya gelir. Hem yapıları itibariyle hantal, hem de üzerlerinde taşıdıkları malzemeler sonucunda ağırlaşmış olan nakliye kayıkları zaten kürekler yardımıyla akıntıya karşı oldukça zor şartlarda ilerlemektedir. Macarlarla bu vaziyette Pozsony yakınlarında karşılaşırlar ve her iki kolun da yenildiğini görünce geri dönmeye çabalarlar. Macarlar, gemileri ele geçirir. Filo komutanı Prens Sieghard ise birliklerinin geriye kalanıla beraber Ennsburg'a çekilir. Bavyera asilzadeleri Rathold, Hattó ve Meinhard ise yapılan çarpışmada hayatını kaybeder. ${ }^{46}$ Aventinus, muharebelerin gelişimini eserinde şöyle kaydeder:

“...yorgun düşen Bavyeralılara saldırdılar, üzerlerine çullandılar, yere ylktılar ve onları öldürdüler... Macarlar geceleyin Tuna'yı gizli bir şekilde karşıya geçtiler, Lajos'un elçisi Luitpold'u... bütün ordusuyla birlikte ordugâhta öldürdüler. Ertesi gün gemilerde bulunanların sonunu getirdiler. Ü̧̧ gün boyunca savaş devaml surette ilahların gazabının orta yerinde devam etti: Bavyera asilzadelerinin büyük kısmı hayatını kaybetti, halk ise hesabı olmayan şekilde yok edildi" ${ }^{47}$

Macarlar üç muharebede de galip geldikten sonra son muharebe için Ennsburg'da bulunan Bavyera birlikleri üzerine yürümeye karar verir. Macar birlikleri bu bölgeye ilerleyerek Bavyera birliklerini önce üzerlerine çekerler. Birlikler yerlerinden ayrılıp pozisyonlarını kaybedince onları iki yandan sararak bozguna uğratırlar. Muharebede Kralın akrabası ve Tuna filosu komutanı Prens Siegrad da hayatını kaybeder. Kral Lajos ve maiyeti zor şartlar altında Passau'ya (Pazorva) çekilir. Kendilerine direniş gösterecek bir kuvvet kalmadığını gören Macarlar çevreye yayılarak ganimet ve esir elde ederler, Lech irmağına kadar olan bölgede bulunan birçok yerleşim yerini ve manastırı yağmalayıp ateşe verdikten sonra geri çekilmeye başlarlar. ${ }^{48}$ Aventius eserinde Macarlar ve Bavyeralılar arasında geçen son mücadeleyi de anlatır:

"Macarlar bu kadar büyük bir zaferden sonra kaçanları kovalayarak ganimetlerle dolu ordugâhlarını ele geçirdiler. Lajos, onları durdurmak için ordusunun dă̆ılmış askerlerini toplad, yanındaki yedek kuvvetlerden yeni birliklerle onu takviye etti. Düşman tarafindan önceden hazırlanmış tuzaktan habersiz şekilde ordusunu ileri çıkardı. Oysaki Macarlar her iki orduyu da gözleyebilecekleri ovanın yanında bulunan ormanda kendilerini gizlemişlerdi. Düşman kaçıyormuş gibi yaptı, bizimkiler onlar sabırsız şekilde kovalarken bütünlükleri bozuldu, muharebe düzenleri dağıldl. Kaçanlar tuzak yerine kadar onları sürdü ve ormanın kenarına gelir gelmez orada gizlenenler haykırarak arkadan aniden bizimkilerin üzerine saldırdılar ve önden kaçanlar da durdular ve kovalayanlarla yüz yüze geldiler. Arkadan, önden, her taraftan sarılmış Bavyeralıları öldürdüler. Kral Lajos, Passau'ya çekildi" ${ }^{49}$

\footnotetext{
${ }^{45}$ Gubcsi, age, s. 9-10; Négyesi, agm, s. 37; Bánlaky, age; Dedek, age.

${ }^{46}$ Négyesi, agm, s. 37; Bánlaky, age; Dedek, age.

${ }^{47}$ Szabados, age, 2015, s. 90.

${ }^{48}$ Bánlaky, age; Harmat, agm, 2012; Dedek, age.

${ }^{49}$ Béla Torma, "Megjegyzések a 907. és 910. évi magyar kalandozások időrendjéhez", Hadtörténelmi közlemények, 125. évf., 2. sz., 2012, s. 474.
} 
Ganimet ve esirlerle geriye dönmekte olan Macarları elde ettikleri ganimetleri geri almak ve esirleri de kurtarmak için Regensburg civarında Kont Schwarzenberg karşılamak ister. Ancak Macarlar, Kont Schwarzenberg'in birliklerini kısa zamanda dağıtırlar ve Schwarzenberg'i birçok asilzade ile birlikte ok yağmuruna tutarak bu girişimi de bertaraf ederler. $^{50}$

Kaynaklar sefer ile ilgili özellikle iki kişinin adını anarlar: Güney kolunu yöneten Başpiskopos Theotmár ve kuzey kolunu yöneten sınır bölgelerinin yöneticisi, Nordgau, Ostmark ve Karinthia markiliklerinin askeri gücünü birleştiren Kont Luitpold. 28 Haziran'dan 5 Temmuz'a kadar süren muharebelerde asıl dönem noktası 4-5 Temmuz 907 tarihlerinde gerçekleşen iki büyük muharebedir. Kaynaklar 28 Haziran'da da büyük bir mücadelenin olduğundan bahseder. Weisseburg'da bulunan mezarlıkta yer alan Piskopos Udo'nun mezar taşında Piskoposun 28 Haziran 907 tarihinde yapılan çarpışmada hayatını kaybettiği yazılıdır. Buna karşın Freising Halottaskönyv'de Kont Luitpold'un 5 Temmuz 907 tarihinde öldüğü kaydedilmiştir. ${ }^{51} \mathrm{Bu}$ kayda rağmen Aventinus eserinde Macarların ırmağı karşıya geçişini ve dolayısıyla Kont Luitpold'un ölümünü ilginç bir şekilde 9 Ağustos olarak gösterir. “A ğustos'un beşinci gününde [yani Ăgustos'un dokuzunda] Macarlar geceleyin gizli bir şekilde Tuna ırmă̆ını karşıya geçtiler..."

İlk çarpışma Tuna'nın güneyinde bulunan Roma döneminden kalma limes yolu üzerinde ilerleyen Başpiskopos Theotmár'ın kuvvetleriyle olur. Çarpışma, Tuna ırmağına yakın bir yerde Pozsony yakınlarında gerçekleşir. 4-5 Temmuz 907 tarihlerinde yaşanan muharebelerin birbiri ardına gerçekleşmesi muharebe alanlarının da birbirine yakın olduğunu gösterir. Buradan Bavyera birliklerinin ve Macar kuvvetlerinin birbirlerinden en fazla bir günlük mesafede oldukları sonucuna ulaşılabilir. Kaynaklar muharebe yeri olarak Pozsony'u anarlar, ancak Pozsony sadece bir yer ismi değildir, aynı zamanda Doğu Frank Krallığı'nın Pannonia sahasındaki son askeri yöneticisi olan Braszlav'ın (884-900) ikamet ettiği kaleyi de (Brezalauspurc) işaret eder. Kalenin güçlendirilmesi muhtemelen Braszlav ile bağlantılıdır. Doğu Frank Krallığı'nın sınır noktasında bulunan bu yer stratejik açıdan da son derece önemlidir. Aynı zamanda Antik Roma limes yolu Pozsony yakınlarında eski bir ticaret yolu olan borostyánkőút (Borostyánút/Amber [Kehribar] Yolu) ile kesişir ve eskiden beri Frank topraklarına güvenli bir geri çekilme imkânı sunar. Bavyera ordusu herhangi bir olumsuz durumda rahatça geri çekilebilmek için bu güzergâhı da tercih etmiş olabilir. Zira kuzeydeki yükseltiler Csallóköz'e doğru bir köprübaşı oluştururken batıya doğru Moravya 1rmağı ve Küçük Karpatlar doğal bir engeldir. Doğu yönünde ise Győr'e kadar Szigetköz bataklıkları ilerleyen birliklerin önünü keser. ${ }^{53}$

Başpiskopos Theotmár'in, Kont Luitpold'un ve Kral Lajos'un Ennsburg'da bulunan birlikleri ile yapılan muharebelerin ve Tuna filosunun ele geçirilmesi sonucunda Bavyera ordusunun kayıları büyük olur. Kont Luitpold, Başpiskopos Theotmár ile birlikte Piskopos Udo, Freising Piskoposu Ottó, Säben Piskoposu Zakariás, üç keşiş ve on iki Bavyera ileri geleni hayatını kaybeder. Nitekim Sváb Yıllı̆̆ı muharebeyi "Prens Luitpold'un öldüğ̈̈, sinırsız gururlarının kırıldı̆̆ ve Hristiyanların birkaçının güçlükle kaçabildiği, piskoposların ve kontların büyük çoğunluğunun öldüğ̈̈ Bavyeralıların Macarlarla yaptıkları perişan bir

\footnotetext{
${ }^{50}$ Bánlaky, age.

${ }^{51}$ Gubcsi, age, s. 12; Hóman-Szekfü, age.

${ }^{52}$ László Veszprémy, “Aventinus híradása a magyarok 907. évi győzelméröl. Csata Pozsonynál”, Történeti szemle, 49. évf., 1. sz., 2007, s. 15. Aventinus bu noktada Eski Roma takviminde her ayın ortası olarak kabul edilen ides sistemini temel alır.

${ }^{53}$ Gubcsi, age, s. 12; Négyesi, agm, s. 37; Torma, age, 2008, s. 39.
} 
mücadeledir. Macarlar, Bavyeralıların bütün ordusunu yok ettiler" şeklinde anlatır. ${ }^{54}$ Ayrıca "Başpiskopos Dietmár, piskoposlar Ottó ve Zakariás ve birçok başrahip muharebe sahasında hayatını kaybetti ve ordugâhlarında bulunan hazineleri galip gelen Macarlar paylaştılar" şeklinde bir ifade de kullanır.

Büyük Károly’un (768-814) Avarlara karşı tesis ettiği Ostmark Markiliği, Pozsony Muharebesi ile tarihe karışır. Sahası Enns ırmağına kadar Macarların eline geçer ve aynı zamanda Karinthia Markiliği'nin doğu bölümü olan Steiermark da (günümüzde Avusturya'nın güneydoğu kısmında bulunan bir eyalet) Macarların sınır bölgesi olur. "zaferden sonra Macar ordusu Enns'e kadar ilerler", ırmak, "bunu takiben 955'e kadar sinır çizgisidir" Macarlar, batı yönünde ilerlemek için oldukça elverişli yollar ve geçitler elde ederler. Mağlubiyetten sonra Macarlara batı yönünden 1030 yılına kadar yüz yirmi üç yıl boyunca herhangi bir saldırı gerçekleşmez. Ancak 11 Temmuz 1030 tarihinde Kutsal Roma İmparatoru II. Konrád (1024-1039) Macarlar üzerine bir ordu gönderir. 4-5 Temmuz 907 tarihinde gerçekleşen Pozsony Muharebesi ile yurt tutuş süreci nihai olarak sona erer. Bu muharebe ile Macarlığın Avrupa'da varlığını sürdürecek yeterli gücü olduğu ve Karpatlar Havzası'nda artık daimî şekilde yerleşmekte olduğu anlaş1lır. ${ }^{57}$

\section{Pozsony Muharebesi'nin Değerlendirilmesi}

Pozsony Muharebesi, yurt tutuş döneminin en önemli gelişmesidir ve Macar tarihinin dönüm noktalarından birini oluşturur. Zira Macarların Karpatlar Havzası'na geldikten sonra hasımları olan Doğu Frank Krallığı'nın Macarları geri püskürtme çabaları bu muharebe ile son bulur. Bu sefer, Macarların 895-896 yıllarında başlayan yurt tutuş süreci içinde Avrupa topraklarında Macarlara karşı yapılan en büyük ve en güçlü harekâttır. Macarlar, bu muharebede galip gelmekle Karpatlar Havzası'nı Avar Kağanlığı'nın (562-823) çöküşünden sonra kontrol eden ve Avrupa'da söz sahibi olan Doğu Frank Krallığı ile mücadele edebilecek güçte olduklarının da işaretini verir. ${ }^{58}$

Bu muharebe dönemin çağdaş yazınında ayrıntılı şekilde yer bulmaz, Macarlar tarafından da kaleme alınmaz. Orta Çăg kaynakları arasında sadece Alman yıllıkları bu muharebeden bahseder; muharebe Salzburg ve Sváb yıllıklarında kendisine yer bulur. Ancak muharebe hakkındaki ayrıntıları muharebenin üzerinden altı yüz yıldan fazla bir zaman geçtikten sonra Bavyeralı kronik yazarı Johannes Aventinus (Turmair, 1477-1534), Bajor évkönyv (Bavyera Yıllığı) adlı eserinde verir. Bununla birlikte yazdıklarını dönemin başka kaynaklarından doğrulamakta güçlük çekildiğinden ve yaşananları oldukça uzun bir süre sonra kaleme aldığından dolayı ne kadar gerçekçi oldukları konusunda şüpheler bulunmaktadır. ${ }^{59}$

Zira bu konudaki bir görüş, 791 yılında Pannonia'daki Avarlar üzerine yürüyen Büyük Károly'un seferinin anlatımı ile Pozsony Muharebesi'nin anlatımı arasında benzerlikler bulunduğu şeklindedir. Aventinus'un eserinde Pozsony Muharebesi'nin anlatımının bu seferin ana hatları üzerine kurgulandığ 1 düşünülmektedir. ${ }^{60}$ Kronik yazarının anlatımından ve

\footnotetext{
${ }^{54}$ Szabados, agm, 2007, s. 64; Torma, agm, 2012, s. 474, 476.

${ }^{55}$ Dedek, age.

${ }^{56}$ György Antal Diószegi, “A 907. évi pozsonyi diadalunk egyetemes jelentősége 1111 év távolából: történelmi áttekintés”, Aracs: a délvidéki magyarság közéleti folyóirata, 18. évf., 3. sz., 2018, s. 45.

${ }^{57}$ Harmat, agm, 2012; Hóman-Szekfü, age; Négyesi, agm, s. 37; Bánlaky, age; Nagy, age, s. 370.

${ }^{58}$ Bánlaky, age.

${ }^{59}$ Zsolt Petkes, “A honfoglaló magyarság fegyverzete a pozsonyi csata tükrében”, Határtalan régészet, 2. évf., 4. sz., 2017, s. 56.

${ }^{60}$ Négyesi $a g m$, s. 36.
} 
kullandığı kelimelerden Annales regni Francorum (741-829 yılları arasında gerçekleşen olayları anlatan Frank yıllığı) adlı eseri bildiği de güçlü bir ihtimaldir. ${ }^{61}$

Öte yandan Ennsburg kalesinin adını da Fulda Yıllıkları'nda (900 civarı) bulabiliriz. ${ }^{62}$ Bundan başka gemilerin ilerlemekte olan birliklere asker ve iaşe sağlaması durumuna başka eserlerde, örneğin 899 yılındaki Fulda Y1llıkları'nda da rastlanır. Aventinus, bu olayı uygun şekilde kendi eserine adapte etmiş olabilir. ${ }^{63}$ Ayrıca muharebelerin başlangıç zamanı da Salzburgi Évkönyvek'de (Salzburg Yıllıkları) yer alan kayda göre belirlenir: "Temmuz'un 4'ünde Brezalauspurch'da çok şanssız bir muharebe yaşandı","4 Bundan başka Bavyera ordusunun harekete geçtiği tarih olarak kabul edilen 17 Haziran 907, Passau Piskoposu Burchard'ın isminin de yer aldığı krallık bağış belgesinden yola çıkılarak kabul edilmiştir. Piskoposun varlığı ve Kralın Ennsburg'daki yenilgiden sonra Passau'ya çekilişi Aventinus tarafından kaleme alınan olayların sırasına ve şekline uygundur. Seferin başladığı gün Kralın yanında Ennsburg'da kalmış olan Kont Aribó da anlatımlara uygun düşmektedir. Ennsburg'da yaşanan muharebede hayatını kaybetmediğini daha geç dönemdeki kaynaklar da doğrulamaktadır. ${ }^{65}$ Aventinus'un kaleme aldıkları konusunda soru işaretleri bulunsa da eseri, dönemin suskun kaynakları arasında yine de ayrı bir yerde durmaktadır.

Macarların bu muharebede kullandığı taktik, Avrupa ordularının o zamana kadar görmediği ve alışkın olmadığı bir taktiktir. Macarlar, Pozsony Muharebesi’nde hafif süvarilerle saldırı ve geri çekilme taktiğini başarılı şekilde uygularlar. Hunlar 451 yılında ve Avarlar da 790 civarında bu taktikle mücadele etmişlerdir. Batı Avrupa orduları steplerin göçebe halklarının savaş taktiklerini anlamakta ve yorumlamakta uzun süre güçlük çekerler. Macarların savaş taktiğini ise ancak 10 Ağustos 955 tarihinde Augsburg'da çözerler ve Macarlar karşısında galibiyet elde ederler. ${ }^{66}$ Aventinus, Pozsony Muharebesi'nde Macarların kullandığg taktiği açıkça belirtir. Gerçi bu taktik Regino'nun (842 civarı-915) ve Liutprand'ın (922-972?) eserlerinde de görülür. Regino'nun 889 tarihli Chronicon adlı eserinde Macarların yakın muharebe ve kale kuşatmalarında çok da başarılı olmadığını ancak sahte geri çekiliş taktiğinde ustalaştıklarını okuruz. ${ }^{67}$ Macarlar hem Başpiskopos Theotmár'ın, hem Kont Luitpold'un ve hem de Kral IV. Lajos'un birliklerini aynı taktiği kullanarak mağlup ederler. Önce küçük birlikler halinde sürekli olarak düşman saflarına saldırarak onları hem moral açısından yıpratıyor, hem fiziki açıdan yoruyor ve hem de her yandan yapılan saldırılar sonucunda birliklerin şaşırmalarına ve korkmalarına sebep oluyorlardı. Bu şekilde düşmanı zayıflattıktan sonra sahte bir geri çekiliş taktiği uyguluyorlar, düşman birlikleri de Macarların yenildiğini veya güçlerinin kalmadığını düşünüp savunma pozisyonundan çıkıp hücum durumuna geçiyor ve mevzilerini terk ediyorlardı. Bu şekilde Macarlar düşmanın zayıf bir anını kollayıp önce ok atışlarıyla düşmanı kayba uğratıyor, sonra da her yandan sararak nihai bir muharebede düşman birliklerini yok ediyordu. ${ }^{68}$ Aventinus, Macarların taktiğini şöyle anlatır:

"Çevik atlarıyla safları parçalamak ister gibi büyük bir kuvvetle saldırdılar ve müthiş şekilde ok attılar. Bavyeralıları yaylarından boşalan oklarla alt ettiler, sonra

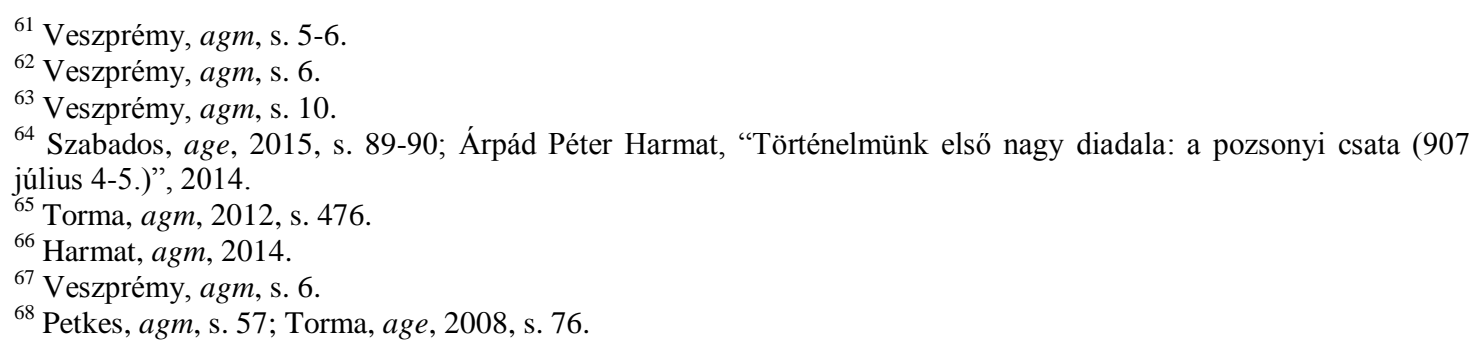


yeniden geri çekildiler. [...] ...şiddetli bir saldırı ile ortaya çıktılar, aynı şekilde aniden ortadan kayboldular, ilk başta geri çekiliyormuş gibi yaptılar, sonra atlarını geri çevirerek saldırdılar, fakat nasıl olursa olsun ok attılar ve mızrak firlattılar ..."69

Ayrıca “...Fırtına gibi hücum eden Macar süvarilerinin saldırısı dehşet vericiydi; ok yağmuru Bavyeralıların sıkışık saflarında hatırı sayılır ölçüde kayba sebep oldu; lakin kısa ve şiddetli saldırı, güçlü görülen ordugâhın bütün direncini bir anda kırmayı başaramadı. Bu arada Macarlar amaçlarına ağır ă̆ır, fakat kesin bir yöntem izleyerek eriştiler. Giderek daha küçük birlikler halinde rastgele düşmana hücum ettiler ve hem Alman ordugâhına saldırı esnasında hem de kovaladıklarının üzerlerine durmadan ok atarak geri çekilmeleri sırasında hep birlikte hızlı bir şekilde hareket ettiler. Düşman bu sürekli saldirllardan yoruluncaya, gücünü ve cesaretini kaybedinceye kadar gece gündüz, her tarafta aralıksız çarpışmaya devam ettiler..."

Aventinus, Macar birliklerinin hızlı ve atılgan taktiğinden de bahseder: “... A $\breve{g}_{l}$ r silahlarla donanmış ordumuzdan daha hızlılar, uzakta olduklarına inandığımız zaman artık hem orada görülürler ve hem de hızlı bir şekilde ortaya çıktıları gibi, hızlı bir şekilde ortadan kaybolurlar. Galip geldiğini zannettiğin zaman kendini büyük bir tehlike içinde bulursun..."71

Macarların Pozsony Muharebesi'nde kullandığı silahlar, Macar birliklerinin ne şekilde mücadele ettiğini ve Macarların muharebe taktikleri hakkında da ipuçları verir. Bajor Évkönyv'de anlatılanları yüzyıllar sonra gün ışığına çıkan arkeolojik verilerle beraber düşündüğümüz zaman Pozsony Muharebesi'nde Macarların atl1-okçu savaşçılardan oluşan süvari birlikleri ile mücadele ettiği sonucuna varırız. Zaten muharebede kullanılan silahlar da bunu kanitlamaktadır. Sadaklar, oklar ve yaylar Macarların piyade taktiğinden ziyade atlı birliklerle savaştığının bir göstergesidir. Macar askeri tarihçi Lajos Négyesi, yurt tutuş zamanındaki Macar atl1-okçu muharebe birliklerinin önemini şu cümlelerle vurgular:

"Batı ordularında da hafif silahl birlikler bulunmasına rağmen bu ordular Macar akıncıları karşısında genellikle mağlup oluyorlardı. Bu şekilde Macarlar muharebe zamanında da bütün muharebe sahasını kontrol altında tutuyorlardl. Kapalı düzende duran Batı Avrupa orduları her yönde son derece hızl hareket eden atl-okçu birlikleri görüyor ve sürekli bir ok yağmuruna karşı koymaları gerekiyordu. Yaralıların çok olmasının yarattı̆̆ umutsuzluk, kuşatılmışlık hissinin de artması onları hücuma başlamak için harekete geçiriyordu." 72

Macarlar yakın muharebeyi her ne kadar tercih etmese de seferlere yine de dönemin yakın muharebe silahları olan kılıç ve savaş baltası kuşanarak çıkarlardı. ${ }^{73}$

Hiç kuşku yoktur ki X. yüzyılda, yurt tutuş sürecinde Macarlar tarafından kullanılan en etkili ve önemli silah 110-120 cm. uzunluğunda olan oktur. Bu okların menzilleri 200 metreye kadar çıkabiliyordu. Okların muhafaza edildiği sadaklar ve çekildiği yaylar da en az oklar kadar önemlidir. ${ }^{74}$ Nitekim Orta Çağ'da Avrupa kiliselerinde "Tanrım! Bizi Macarların

\footnotetext{
${ }^{69}$ Szabados, age, 2015, s. 90; Petkes, agm, s. 56.

${ }^{70}$ Dedek, age.

${ }^{71}$ Szabados, age, 2015, s. 90.

${ }^{72}$ Négyesi Lajos, A magyar hadművészet a 907. évi pozsonyi csata idején. In: Egy elfeledett diadal. A 907. évi pozsonyi csata. Bp., 2008. 172. o.’dan aktaran György Antal Diószegi, “A 907. évi pozsonyi diadalunk egyetemes jelentősége 1111 év távolából: történelmi áttekintés”, Aracs: a délvidéki magyarság közéleti folyóirata, 18. évf., 3. sz., 2018, s. 45-46.

${ }_{74}^{73}$ Petkes, agm, s. 57.

${ }^{74}$ Petkes, agm, s. 57-58.
} 
oklarından kurtar!" şeklinde dualar edildiği bilinmektedir. ${ }^{75}$ Reis Árpád (845-907) döneminde Macarların uyguladığı savaş taktiklerinde ok ve yay büyük yer tutar, okun düşmanın yıpratılmasında ve muharebelerin kazanılmasında önemli rolü olduğu bilinir. Dolayısıyla Pozsony Muharebesi'nde de okun ve yayın büyük oranda belirleyici olduğunu söylemek yanlış olmayacaktır. ${ }^{76}$

Oktan başka mızrak da atlı-göçebe halkların muharebe taktiklerinde oldukça önem kazanmıştır. Macarlardan bahseden Bizans İmparatoru VI. (Bilge) Leo da (886-912) Macarların muharebelerde mızrak kullandığını yazar. Mızrak, göçebe halklarda sadece saldırı amacıyla değil, aynı zamanda düşmanla mücadele için de kullanılır. Aventinus eserinde mızrağın bir çeşidi olan kargıdan bahseder. Aventinus'a göre Macarlar yakın muharebe bilmezler ve kılıç da kullanmazlard1. ${ }^{77}$ "Macarlar düşmanlarına uzaktan attıkları oklarıla saldırırlar: O günlerde okla yapılan bir mücadele bilinmezdi, birbirine yanaşık piyade safları, kıllçla yakın muharebe yapardl...,"78

Arkeolojik buluntular içinde ucu kıvrık kılıçlar olduğu gibi Avrupa tarzı iki tarafı keskin kılıçlar da keşfedilmiştir. X. yüzyılın ilk yarısında ucu eğri kılıçlar kullanılırken, yüzyılın ortasından itibaren iki tarafı keskin Avrupa tarzı kılıçların kullanılmaya başlandığı görülür. 907 yılında Macarlarla karşı karşıya gelen Bavyera-Frank ordusunun silahları da o dönemde kullanılan geleneksel silahlardır (mızrak, iki tarafı keskin kılıç, balta vb.). Bununla birlikte Bavyera-Frank ordusunun sayıca Macar ordusundan daha fazla olmasına rağmen Macarların savaş taktiğine yabancı olması, süvarileri etkin şekilde kullanamaması ve Macar birliklerine göre daha ağır bir yapıda olması mağlup olmalarına sebep olur. ${ }^{79}$ Bavyera ordusunun mağlup olmasının diğer bir sebebi de Tuna ırmağının iki kıyısında ilerleyen kuvvetlerin filoya rağmen birbiri ile tam olarak iletişim kuramamaları, bunun sonucunda her iki kolun birbirinden ayrı hareket etmesi, kuvvetlerini bir araya getirememesi ve Macarların karşısına tek bir ordu halinde çıkamamalarıdır. ${ }^{80}$

Pozsony Muharebesi ile ilgili en önemli noktalardan birisi de Macar kavim birliğini Karpatlar Havzası'na getiren, Karpatlar Havzası'nın ele geçirilmesinde önemli rolü bulunan ve ilk iskân faaliyetlerinin yapılmasını sağlayan Reis Árpád'ın muharebe sırasında hayatta olup olmadığıdır. Reis Árpád'ın bu savaş sırasında hayatını kaybettiği veya ağır yaralanıp 9 Temmuz 907 tarihinde öldüğü ile ilgili görüşler de vardır. Bir başka görüş de hem Árpád'ın kendisinin, hem de Tarhos, Üllő ve Jutas adlarını taşıyan üç oğlunun da bu muharebede yaşamını yitirdiğidir. Macar yazarı Attila Bánó (1945- ), Reis Árpád'ın Frank ordusu sefere çıkmadan önce öldüğünü ve ölüm haberinin Doğu Frank Krallığı'nı sefer konusunda cesaretlendirdiğini iddia eder. ${ }^{81}$ Zira Doğu Frank Krallığı, Macar kavim birliğinin yöneticisiz kaldığını, düzeninin bozulduğunu düşünmüss ve bu firsatı değerlendirmek istemiş olabilir. Macar tarihçileri Bálint Hóman (1885-1951) ve Gyula Szekfü (1883-1955) de Reis Árpád'ın muharebeden kısa bir süre önce öldügünü ve Aquincum'un (Roma İmparatorluğu'nun Pannonia eyaletinin kuzeydoğu sınırında bulunan tarihi şehir) harabeleri yakınında yer alan küçük bir ırmağın kaynağı civarına defnedildiğini söyler. ${ }^{82}$ Anonymus eseri Gesta

\footnotetext{
${ }^{75}$ Diószegi, agm, s. 46

${ }^{76}$ Farkas, agm, s. 203.

${ }^{77}$ Petkes, agm, s. 58.

${ }^{78}$ Petkes, agm, s. 57.

${ }^{79}$ Petkes, agm, s. 59; Révész, age, s. 176.

${ }^{80}$ László Töll, "Torma Béla Gyula-Veszprémy László: Egy Elfeledett Diadal. A 907. Évi Pozsonyi Csata", Hadtörténelmi közlemények, 122. évf., 2. sz., s. 552.

${ }^{81}$ Szabados, age, 2015, s. 8, 91-92; Harmat, agm, 2012.

${ }^{82}$ Hóman-Szekfü, age.
} 
Hungarorum'da Reis Árpád'ın ölümü hakkında şöyle der: "Reis Árpád, İsa'nın doğumunun 907. yılında bu dünyadan ayrıldı. Onu yatağının içinde Kral Atilla'nın şehrine akan küçük bir ırmağın kaynağının üst kısmına huşu içinde defnettiler" ${ }^{\prime 3}$ Ayrıca muharebe sırasında Macar birliklerinin başında kimin ya da kimlerin olduğu bilinmemektedir. Kaynaklar Reis Árpád'ın adını anmazlar. Bununla birlikte isim vermeden bir Macar reisinden söz ederler: "Gerçi yenildik, fakat Macarların reisini de mahvettik" ${ }^{\prime 4}$ Ancak muharebe zamanı Árpád hayatta olmasa bile beş oğlu (Levente/Liüntika, Tarhos/ Tarkacsu, Üllö/Jelekh, Jutas/Jutocsa ve Zolta) arasından en büyüğü olan Levente'nin Macar birliklerini yönettiği güçlü bir olasılık olarak düşünülebilir. ${ }^{85}$

Muharebe ile ilgili üzerinde durulması gereken bir başka nokta da muharebeye katılan birliklerin sayısına ilişkindir. Gerek Frank gerekse de Macar ordularının sayısı tam olarak belli olmasa da dönemin şartlarına bakılarak Doğu Frank Krallığı ordusunun en fazla 20-25.000 kişiden oluştuğu, Macarların ise en fazla 10-15.000 askerle mücadele ettiği söylenebilir. Bavyera ordusunun 100.000, Macar ordusunun ise 40.000 askerden oluştuğu şeklindeki görüşler abartılıdır ve gerçeği yansıtmaz. Nitekim muharebeden kırk sekiz yıl sonra gerçekleşen, Macarların macera seferlerinin sonunu getiren, yerleşik düzene geçmelerinde ve Avrupa kültürüne uyum sağlama sürecinin ivme kazanmasında rol oynayan 955 yılında gerçekleşen Augsburg Muharebesi'nde bile 10.000'in altında asker mücadele edilmiştir. ${ }^{86}$

\section{Sonuç}

Doğu Frank Krallığı, 907 yılında Karpatlar Havzası'nda 900 yılından beri sürekli olarak güçlenen, Orta Avrupa'da tedirginliğe sebep olan ve Doğu Frank Krallığı'nın mülklerini de tehdit eden Macar tehlikesini ortadan kaldırmak için harekete geçer, ancak 4-5 Temmuz 907 tarihinde gerçekleşen Pozsony Muharebesi sonucunda sadece Bavyera birlikleri yenilgiye uğramakla kalmaz, Macarlar da topraklarını ve hâkimiyetlerini Enns nehrine kadar genişletirler. Bundan başka Moravya Prensliği'nin de Pozsony Muharebesi sonucunda yeniden hayat bulması ihtimalinin ortadan kalkması Macarların batı yönündeki yayılımının önünü açan bir başka faktördür.

Bu muharebe Macarları Karpatlar Havzası'ndan çıkarmayı ve Pannonia'yı tamamen kendi topraklarına katmak isteyen Doğu Frank Krallı̆̆ı'nın amaçlarına ulaşmasını engellediği gibi, aynı zamanda Doğu Frank Krallı̆̆ı'nın gücünü kırdıktan sonra Macarların Karpatlar Havzası'na sağlam ve kalıcı şekilde yerleşmesini sağlar, böylece Orta Çağ Macar Krallığı'nın da kuruluş sürecinin temelleri atılır. Pozsony Muharebesi ile Macar kavimlerinin yurt tutuş süreci sona erer, Macarların batı sınırı belli olur. Bu muharebe X. yüzyıl Avrupa tarihinin önemli muharebelerindendir.

Pozsony Muharebesi'nde Macarların varlı̆̆ı Avrupa'da kesinleşirken, 955 yılında gerçekleşen Augsburg Muharebesi sonrası Macarlar adına Avrupa kültürünü daha yakından tanıma, bu kültüre uyum sağlama sürecinin ve yeni bir inancın kabulünün ilk aşamaları başlar. Pozsony Muharebesi, Macarlar açısından deyim yerindeyse bir ölüm-kalım mücadelesidir. Macarlar, bu muharebeden yenik ayrılsaydı Karpatlar Havzası'ndaki durumları sarsılacak ve belki de Avrupa kıtasındaki varlıklarının sonu gelecekti. Pozsony Muharebesi, Macarların Avrupa'ya kabulünü sağlar, Macarları Avrupa'nın bir öğesi haline getirir ve kıtadaki diğer

\footnotetext{
${ }^{83}$ Szabados, agm, 2007, s. 64.

${ }^{84}$ Harmat, agm, 2014.

${ }^{85}$ Harmat, agm, 2012; Harmat, agm, 2014.

${ }^{86}$ Harmat, agm, 2012.
} 
devletler de Karpatlar Havzası'nda artık yeni bir gücün var olduğunun ve özellikle Orta Avrupa' da yaşanan oluşumlarda bu gücü de hesaba katmak gerektiğinin bilincine varır.

Avar Kağanlığı'nın ortadan kalkmasından yaklaşık yüz yıl sonra Avrasya step kuşağının son halkası olan Karpatlar Havzası yine atlı-göçebe bir halkın eline geçer ve bu gelişme Avrupa'nın, özellikle de Orta Avrupa'nın tarihi, politik ve kültürel gelişimini derinden etkiler. 907 yılında yaşanan Pozsony Muharebesi ile Macarlar, Doğu Frank Krallığı'nın doğu yönündeki yayılımının önüne geçerler ve Avrupa kıtasında var olan güçler arasındaki yerlerini alırlar. Macarlar zaten 892 yılından beri Avrupa'da siyasi bir faktör olarak kabul edilmektedir. Pozsony Muharebesi ile bu durum kesinlik kazanır. Zira Macarlar Avrupa kültürüne uyum sağladıktan ve Hristiyanlığı kabul ettikten sonra Avrupa kıtasında varlıklarını daha da sağlamlaştırırlar ve ilerleyen yıllarda Avrupa'da yaşanan siyasi, askeri ve kültürel oluşumlarda etkili şekilde yer alırlar.

\section{KAYNAKÇA}

BÁNLAKY, József, A magyar nemzet hadtörténelme, (Digitális kiadás: Arcanum Adatbázis Kft.), $2001 \quad$ (http://mek.oszk.hu/09400/09477/html/0002/69.html) (18.12.2018)

DEDEK, Crescens Lajos, "Pozsony Vármegye Története”, Magyarország Vármegyéi és Városai, Szerkesztő: dr. Borovszky Samu (Digitális kiadás: Arcanum Adatbázis Kft.), 2004 (http://mek.oszk.hu/09500/09536/html/0017/25.html) (20.12.2018)

DİÓSZEGİ, György Antal, “A 907. évi pozsonyi diadalunk egyetemes jelentösége 1111 év távolából: történelmi áttekintés”, Aracs: a délvidéki magyarság közéleti folyóirata, 18. évf., 3. sz., 2018, s. 45-52.

ECKHART, F., Macaristan Tarihi, (çeviren: İbrahim Kafesoğlu), 2. Baskı (Tıpkı basım), Türk Tarih Kurumu Basımevi, Ankara 2010.

FARKAS, Péter, "A pogányokkal vívott nagyon szerencsétlen harc", Aetas, 25. évf., 2. szám, 2010, s. 202-205.

GUBCSİ, Lajos, “1111 évvel ezelöt A 907-es pozsonyi csata”, 2018.

GÜNGÖRMÜŞ, Naciye, Macaristan'da Değişim ve Demokrasiye Geçiş (1989-2009), Köksav, Siyasal Kitabevi, Ankara 2010.

HARMAT, Árpád Péter, A pozsonyi csata (907 július 4-5), 2012

(http://tortenelemcikkek.hu/node/230) (18.12.2018)

HARMAT, Árpád Péter, Történelmünk első nagy diadala: a pozsonyi csata (907 július 4 5.), 2014

(https://tortenelemtanulas.blog.hu/2014/07/04/ma_van_tortenelmunk_legelso_nagy_diada lanak pozsonyi csatanak evforduloja) (19.12.2018)

HÓMAN, Bálint-Szekfü Gyula, Magyar Történet, Királyi Magyar Egyetemi Nyomda, Budapest 1928 (http://www.elib.hu/00900/00940/html/) (19.12.2018)

KRİSTÓ, Gyula-Barta János-Gergely Jenő, Magyarország Története Előidőktöl 2000-ig, Pannonica Kiadó, (basım yeri belirtilmemiş) 2002. 
NAGY, Kálmán, “A 895. Évi Honfoglalás”, Magyar Történelem Tízezer év - ezer oldalról, szerkesztő: Csihák György, Acta Historica Hungarica Turiciensia, XVIII. évfolyam, 1. szám, ZMTE (Zürichi Magyar Történelmi Egyesület), 37. sz. kiádvanya, Zürich-Budapest, 2002.

NÉGYESİ, Lajos, “A pozsonyi csata”, Rubicon, 2016, 27. évf., 7. sz., s. 36-37.

PETKES, Zsolt, "A honfoglaló magyarság fegyverzete a pozsonyi csata tükrében", Határtalan régészet, (2. évf.), 4. sz., 2017, s. 56-59.

PÖSTÉNYİ, András, Már Kiirtani Sem Akarták A Magyarokat?, 2015 (https://tenyleg.com/index.php?action=recordView\&type=places\&category_id=3 $\underline{115 \& \mathrm{id}=1308636})(17.12 .2018)$

RÁSONYİ, László, Tarihte Türklük, Üçüncü Bask1, Türk Kültürünü Araştırma Enstitüsü Yayınları: 126, Seri: III - Sayı: A.34, Ankara Üniversitesi Basımevi, Ankara 1993.

RÉVÉSZ, László, “A 907. Évi Pozsonyi Csata Katonapolitikai Háttere És Hadművészeti Modellezése”, Egy Elfeledett Diadal. A 907. Évi Pozsonyi Csata, Sz. Torma Béla Gyula és Veszprémy László, Budapest 2008.

SZABADOS, György, "Mítoszok és történetek Álmosról és Árpádról”, Már A Múlt Sem A Régi... Az Új Magyar Mitológia Multidiszciplináris Elemzése, Szer. Hubbes László- Povedák István, Innovariant Nyomdaipair Kft., Szeged 2015.

SZABADOS, György, "907 emlékezete”, Tiszataj, 61. évf., 12. sz., 2007, s. 64-70.

SiPKA, László, “A győztes pozsonyi csata 1100. évfordulójára”, Honismeret, 35. évfolyam, 6. sz., 2007, s. 3-6.

TORMA, Béla, "Megjegyzések a 907. és 910. évi magyar kalandozások időrendjéhez", Hadtörténelmi közlemények, 125. évf., 2. sz., 2012, s. 463-482.

TORMA, Béla Gyula, “A 907. Évi Pozsonyi Csata Katonapolitikai Háttere És Hadmüvészeti Modellezése”, Egy Elfeledett Diadal. A 907. Évi Pozsonyi Csata, Sz. Torma Béla Gyula és Veszprémy László, Budapest 2008.

TÖLL, László, “Torma Béla Gyula - Veszprémy László: Egy Elfeledett Diadal. A 907. Évi Pozsonyi Csata", Hadtörténelmi közlemények, 122. évf., 2. sz., 2009, s. 551 553.

VESZPRÉMY, László, “Aventinus híradása a magyarok 907. évi győzelméről. Csata Pozsonynál”, Történeti szemle, 49. évf., 1. sz., 2007, s. 1-18. 